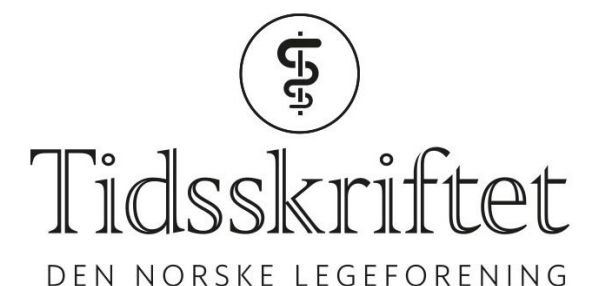

\title{
Felles (nasjonale) referanseområder for antiepileptika
}

KOMMENTAR

\section{BERNT A. ENGELSEN}

E-post: bernt.andreas.engelsen@helse-bergen.no Bernt A. Engelsen er overlege og professor dr.med. ved Epilepsienheten, Haukeland universitetssykehus.

Ingen oppgitte interessekonflikter.

I artikkelen «Felles referanseområder for antiepileptika» presenterte A. Reimers og medforfattere nye referanseområder for serumkonsentrasjon av antiepileptika ved epilepsibehandling.

Undertegnede forstår hensikten med referanseområder for antiepileptika, men ikke hvorfor de må være felles i betydningen nasjonale. Hensikten med at de er oppdaterte (bl.a. reduksjoner i øvre referanseverdi) er også litt uklar for meg. Det hevdes at dette vil «bidra til bedre pasientbehandling», også det er uklart dokumentert for meg.

Kanskje forfatterne kunne si et par ord om hva referanseområder er? Er de vitenskapelig dokumenterte med hensyn til behandlingseffekt, eller er de simpelthen statistisk baserte verdier for serumkonsentrasjoner ved de hyppigste anvendte dosene?

Kliniske farmakologer vet mye om medisiner og serumnivå. Jeg er kjent med Arne Reimers og Cecilie Landmarks forskning og artikler, men bør ikke referanseverdier vurderes av behandlende epileptologer, nevrologer og barneleger som behandler epilepsi, gjennom samtaler med pasient/pårørende, og sett i forhold til effekt og bivirkninger? Jeg tenker at det er vel så viktig som referanseverdier i en del tilfeller.

Harmonisering av referanseverdier nasjonalt tilsier for meg selvfølgelig nasjonal kvalitetssikring av metoder og laboratorieresultater. Er dette gjennomført?

Min lille bekymring grunner seg i min erfaring med behandlingsoppfølging av pasienter med epilepsi fra 1979 til i dag, samt viten om at medisiner mot epilepsi kan være effektive i underkant av nedre referanseverdi, og effektive uten sikre, eller med for pasienten akseptable, bivirkninger i nivåer over angitte referanseverdi. Sistnevnte gjelder etter min erfaring spesielt for lamotrigin, men også eslikarbazepin og levetiracetam.

Kliniske leger opplever rikelig med nasjonale retningslinjer, og selv om RELIS og apotekansatte kan mye og mener vel, blir oppfølging av pasienten i en samvittighetsfull klinisk setting i mine øyne fortsatt viktigst. Referanseverdier for medikamenter er et av flere hjelpemidler i behandlingen, men autoritative nasjonale verdier kan lett virke normsettende i for stor grad i kliniske sammenhenger. 
Publisert: 4. september 2017. Tidsskr Nor Legeforen. DOI: 10.4045/tidsskr.17.0692 (C) Tidsskrift for Den norske legeforening 2020. Lastet ned fra tidsskriftet.no 